\title{
Implementasi Proses Bisnis Dalam Upaya Penerapan Green Hospital
}

\author{
Sofiyanurriyanti \\ Jurusan Teknik Industri, Fakultas Teknik, Sekolah Tinggi Teknik Qomaruddin Gresik \\ Alamat Jalan Raya No. 01 Bungah Gresik, Telp. (031)-3943999, Fax. (031) 3943999 \\ Surel : sofiyanurriyanti20@gmail.com
}

\begin{abstract}
The hospital is a public health service institution. The hospital environment is an aspect that also needs to be considered and managed well. One effort to support the management of a healthy, clean and friendly environment is a green hospital. The application of green hospital covers environment with the green environment, water usage efficiency, electric energy, material use and waste reduction. Evaluation of environmental impact assessment There are several steps including characterization, damage assessment, normalization, weighting and the single score. The methods used under Eco Indicator 99 of some environmental impacts include carcinogens, respiratory organics, climate change, radiation, the ozone layer, ecotoxicity, acidification/eutrophication, land use, minerals, and fossil fuel. While to assess the environmental impact of waste can be seen from the results of life cycle assessment based on characterization, normalization weighting, and the single score. The environmental impacts generated in hospitals affecting human health is $0.153209 \mathrm{Pt}$, eco system quality of $0.178514 \mathrm{Pt}$, and resources $0.359308 \mathrm{Pt}$.
\end{abstract}

Keywords: Green hospital, IDEFO business process, life cycle assessment, simapro.

\begin{abstract}
Abstrak
Rumah sakit merupakan institusi pelayanan kesehatan untuk umum. Lingkungan rumah sakit merupakan aspek yang juga perlu diperhatikan dan dikelola dengan baik. Salah satu usaha untuk mendukung pengelolaan lingkungan yang sehat, bersih dan ramah lingkungan adalah green hospital. Penerapan green hospital ini mencakup lingkungan berwawasan lingkungan hijau, efisiensi penggunaan air, energi listrik, penggunaan bahan material serta pengurangan limbah. Evaluasi penilaian dampak lingkungan ada beberapa langkah meliputi characteristization, damage assessment, normalization, weighting dan single score. Metode yang digunakan berdasarkan Eco Indikator 99 beberapa dampak lingkungan meliputi carcinogens, respiratory organics, climate change, radiation, ozone layer, ecotoxicity, acidification/euthrophication, land use, minerals, dan fossil fuel. Sedangkan untuk menilai dampak lingkungan pada limbah dapat dilihat dari hasil life cycle assessment berdasarkan characterization, normalization weighting dan single score. Dampak lingkungan yang dihasilkan dirumah sakit yang memengaruhi human health sebesar $0.153209 \mathrm{Pt}$, eco system quality sebesar $0.178514 \mathrm{Pt}$, dan resources $0.359308 \mathrm{Pt}$.
\end{abstract}

Kata kunci: Green hospital, proses bisnis IDEF0, life cycle assessment, simapro.

\section{Pendahuluan}

Rumah Sakit merupakan institusi pelayanan kesehatan yang memberikan jasa pelayanan kesehatan dan tempat berkumpulnya orang sakit maupun sehat yang memungkinkan terjadinya pencemaran lingkungan dan gangguan kesehatan [1]. Lingkungan rumah sakit merupakan salah satu aspek yang juga perlu diperhatikan dan juga perlu dikelola dengan baik. Lingkungan sangatlah penting karena aktivitas 
kegiatan yang dilakukan dirumah sakit dapat memberikan kontribusi terhadap kenyamanan pasien. Berbagai aktivitas yang dilakukan rumah sakit memberikan dampak positif bagi masyarakat akan tetapi juga memberikan dampak negatif berupa pencemaran lingkungan. Salah satu contoh dampak negatif dari kegiatan rumah sakit adalah limbah yang dihasilkan dibuang tanpa pengelolaan yang benar sehingga dapat mencemari lingkungan. Pertumbuhan sektor usaha turut berkontribusi pada pencemaran lingkungan seperti pada tahun 2012 sektor perindustrian tumbuh sebesar $11 \%$; sektor bangunan publik sebesar $22 \%$; sektor hotel, gedung perkantoran dan commercial center sebesar 19\%; sektor perumahan sebesar 16\%, sektor rumah sakit sebesar 14\%; sektor sekolah atau institute sebesar 12\% dan sektor manufaktur 6\% [2]. Namun kenyataannya tingkat tingginya pencemaran lingkungan rumah sakit yang masih rendah tidak diikuti dengan pengelolaan limbah yang baik. Pengelolaan limbah rumah sakit di Indonesia saat ini menunjukkan hanya 53,4\% rumah sakit yang melaksanakan pengelolaan limbah cair. Pemeriksaan kualitas limbah yang dilakukan rumah sakit hanya sebesar 57,5\% dan baru sekitar $63 \%$ rumah sakit yang telah memenuhi syarat baku mutu [3]. Menurut Alamsyah [4] limbah yang dihasilkan rumah sakit meliputi limbah non infeksius sebesar $151 \mathrm{~kg} / \mathrm{m}_{3}$ dan limbah infeksius sebesar 262 $\mathrm{kg} / \mathrm{m}_{3}$.Berdasarkan penelitian [5], jumlah limbah yang dihasilkan rumah sakit di negara berkembang cukup bervariasi antara 0,016-3,23 kg/bed hari, sedangkan untuk limbah infeksius bervariasi antara 0,01-0,065 kg/bed hari. Sektor rumah sakit memberikan kontribusi terhadap masalah lingkungan saat ini dengan memproduksi lebih dari 2.4 juta ton sampah per tahun [6].

Beberapa penelitian mengenai green hospital yang dipublikasikan masih terbatas pada area research manajemen lingkungan seperti penelitian yang dilakukan oleh Saputra and Christianti [5] dalam penelitiannya menemukan bahwa bangunan, lingkungan rumah sakit, energi, peralatan laboratorium, peralatan medis dan listrik dapat menjadi pemicu biaya energi utama di rumah sakit. Sebagai tambahan, Diaz, et al. [7] melakukan upaya atau dukungan terhadap manajemen lingkungan kesehatan secara global yang berkelanjutan berbasis pada prinsip green hospital. Sedangkan Alamsyah [4] menekankan bahwa green hospital merupakan konsep rumah sakit yang didesain sebagai sumber daya utama pada rumah sakit yang ramah lingkungan dan lebih menghemat pengeluaran serta lebih memberikan alternatif perbaikan. Pada penelitian ini masih banyak rumah sakit belum mengikuti standar mutu lingkungan sehingga rumah sakit harus mengupayakan usulan perbaikan pengelolaan lingkungan pada limbah rumah sakit. Hal ini dikarenakan rumah sakit selama ini dalam pelaksanaan dan pengelolaan lingkungan pada dasarnya mengacu pada kebijakan nasional dan kebijakan regional. Salah satu upaya pendekatan untuk mendukung pengelolaan lingkungan yang sehat, bersih dan ramah lingkungan dirumah sakit adalah global green and health hospitals. Menurut Diaz, et al. [7] Global green and healhty hospitals merupakan suatu pendekatan "green" dan "healhty" untuk mendukung upaya perbaikan lingkungan rumah sakit secara global berkelanjutan. Beberapa metode dikembangkan untuk melakukan evaluasi terhadap dampak lingkungan salah satunya adalah metode Life Cycle Assessment (LCA). LCA adalah metode untuk mengevaluasi secara sistematis aspek lingkungan pada tahap siklus produk maupun jasa. LCA dapat digunakan untuk mengetahui seberapa besar dampak lingkungan yang disebabkan pada saat pemakaian listrik, air, emisi, dan limbah padat maupun limbah cair oleh konsumen sebagai dasar penentuan alternatif perbaikan [8]. Penelitian ini berupaya untuk mengimplementasi upaya proses bisnis dalam penerapan green hospital pada lingkungan rumah sakit, dan membantu pihak rumah sakit untuk merancang strategi perbaikan lingkungan. 


\section{Metode Penelitian}

Pada penelitian ini dilakukan beberapa tahapan. Pada tahap awal dilakukan proses identifikasi proses bisnis manajemen rumah sakit untuk mengidentifikasi limbah yang dihasilkan selama proses layanan atau kegiatan rumah sakit, serta mengetahui dampak lingkungan terhadap rumah sakit menggunakan life cycle assessment. Tahapan pengembangan ini bertujuan untuk memodelkan fungsi-fungsi aktivitas yang dikembangkan oleh computer aided manufacturing dan kegunaan IDEF0 yaitu membantu dan menganalisis suatu proses bisnis yang berkaitan secara langsung. Ada beberapa metode IDEF0 yang berfungsi sebagai permodelan fungsi, IDEF1 berfungsi untuk permodelan informasi, IDEF1X untuk permodelan data, IDEF2 berfungsi untuk simulasi permodelan,IDEF3 berfungsi untuk proses permodelan, IDEF4 untuk berorientasi pada objek. Pengolahan data yang dilakukan menggunakan data pemakaian air, data pemakaian listrik, data limbah rumah sakit yang dihasilkan. Kemudian dari data tersebut akan dilakukan mengidentifikasi dampak lingkungan menggunakan life cycle assessment (LCA) yang berdasarkan eco indicator 99.

Pada tahap implementasi pengembangan aktivitas proses bisnis IDEF0 (Integration Definition for Function Modelling) dengan menggunakan peracangan sistem permodelan yang sangat komunikatif dan mudah untuk dipahami oleh organisasi, perusahaan, maupun instansi. Tahap permodelan IDEF0 (Function Modelling Method) digunakan untuk mengambil keputusan pada organisasi ataupun sistem. Salah satu diagram IDEF0 didalam struktur permodelan IDEF0 ini memiliki sub fungsi $\mathrm{A}_{0}, \mathrm{~A}_{1}, \mathrm{~A}_{2}, \mathrm{~A}_{3}$ dan seterusnya. Tahap IDEF1 (Information Modelling Method) merupakan metode untuk mendesain dengan mengomunikasikan masuknya permintaan dari konsumen. Tahap IDEF3 (Process Decription Capture Method) merupakan proses penggambaran untuk melakukan dan pembuatan dokumentasi. Tahap IDEF4 merupakan permodelan digunakan untuk petunjuk di dalam pemeriksaan atau pengawasan dari sistem. Setelah mengetahui proses bisnis rumah sakit yang akan dilakukan maka tahap upaya yang dilakukan dengan pendekatan life cycle assessment ada beberapa tahapan yang akan dilakukan antara lain:

a. Menentukan tujuan, menentukan ruang lingkup pada tahap LCA antara lain cradle to grave merupakan ruang lingkup pada bagian ini dimulai dari raw material sampai pada pengoperasian pada produk. Cradle to gate merupakan ruang lingkup pada analisis daur hidup dimulai dari raw material sampai ke proses gate sebelum dilakukan proses operasi. Gate to gate merupakan ruang lingkup pada analisis daur hidup yang terpendek karena hanya meninjau pada kegiatan yang terpendek. Cradle to cradle merupakan bagian dari analisis daur hidup yang menunjukkan ruang lingkup dari material sampai pada daur ulang material [9].

b. Analisis life cycle inventory (LCI) merupakan tahap melakukan masukan dan keluaran yang berhubungan lingkup studi. Dari setiap siklus hidup rumah sakit. Tahapan LCI pada penelitian ini dilakukan pengumpulan data dan analisis semua fasilitas dan kegiatan operasional rumah sakit terhadap pasien menginap.

c. Penilaian life cycle impact assessment (LCIA) yaitu dengan perhitungan nilai dampak lingkungan yang telah dikumpulkan dari tahapan life cycle inventory (LCI).Pada tahap ini terdiri dari tiga langkah utama yaitu characterization, normalization, weighting. Karakterisasi menyediakan untuk membandingkan secara langsung hasil dari LCI dalam tiap kategori yang akan dilakukan. Hal ini dapat dilakukan dengan cara weighting atau pembobotan dilakukan dengan cara mengalikan hasil normalisasi nilai potensial oleh faktor bobot, setelah langkah 
pembobotan semua potensi terhadap dampak lingkungan akan dikonversi ke single user atau nilai tunggal.

d. Interpretasi Siklus Hidup merupakan tahapan setelah LCIA. Pada tahap ini hasil dari LCI dan LCIA yang dibahas sebagai dasar kesimpulan dan rekomendasi rencana perbaikan, mengevaluasi dari hasil siklus hidup atau penilaian dampak siklus hidup. Merupakan langkah perbaikan, simpulan, rekomendasi, pengambilan keputusan yang ditunjukkan untuk membandingkan produk yang ramah terhadap lingkungan. Pada tahap ini akan diintrepretasi yang nantinya untuk menurunkan pada dampak lingkungan yang ditimbulkan pada sistem, produk atau pada proses yang akan diamati.

\section{Hasil dan Pembahasan}

Hasil pengamatan kondisi eksisting rumah sakit menunjukkan bahwa rumah sakit belum pernah menerapkan proses bisnis dan belum juga menerapkan green hospital sebagai salah satu upaya implementasi life cycle assessment. Tahapan-tahapan yang dilakukan dalam proses bisnis IDEF0 di industri rumah sakit ini dalam permodelan proses bisnis tahap awal yaitu mengetahui alur aktivitas yang terjadi di dalam proses bisnis dari awal kegiatan sampai akhir kegiatan. Proses bisnis pada tahap awal ini digambarkan secara umum dengan konteks diagram. Pada tahap konteks diagram dari proses bisnis rumah sakitdapat dlihat pada Gambar 1. Merupakan diagram konteks pada proses bisnis IDEF0 level 0 layanan utama. Proses bisnis pada layananan utama rumah sakit umum dilakukan pemetaan proses bisnis yang ini terdiri dari 4 tahap antara lain terdapat 5 input dengan kode (A), 4 control dengan kode (B), mechanism dengan kode (C) sedangkan output dengan kode (D).

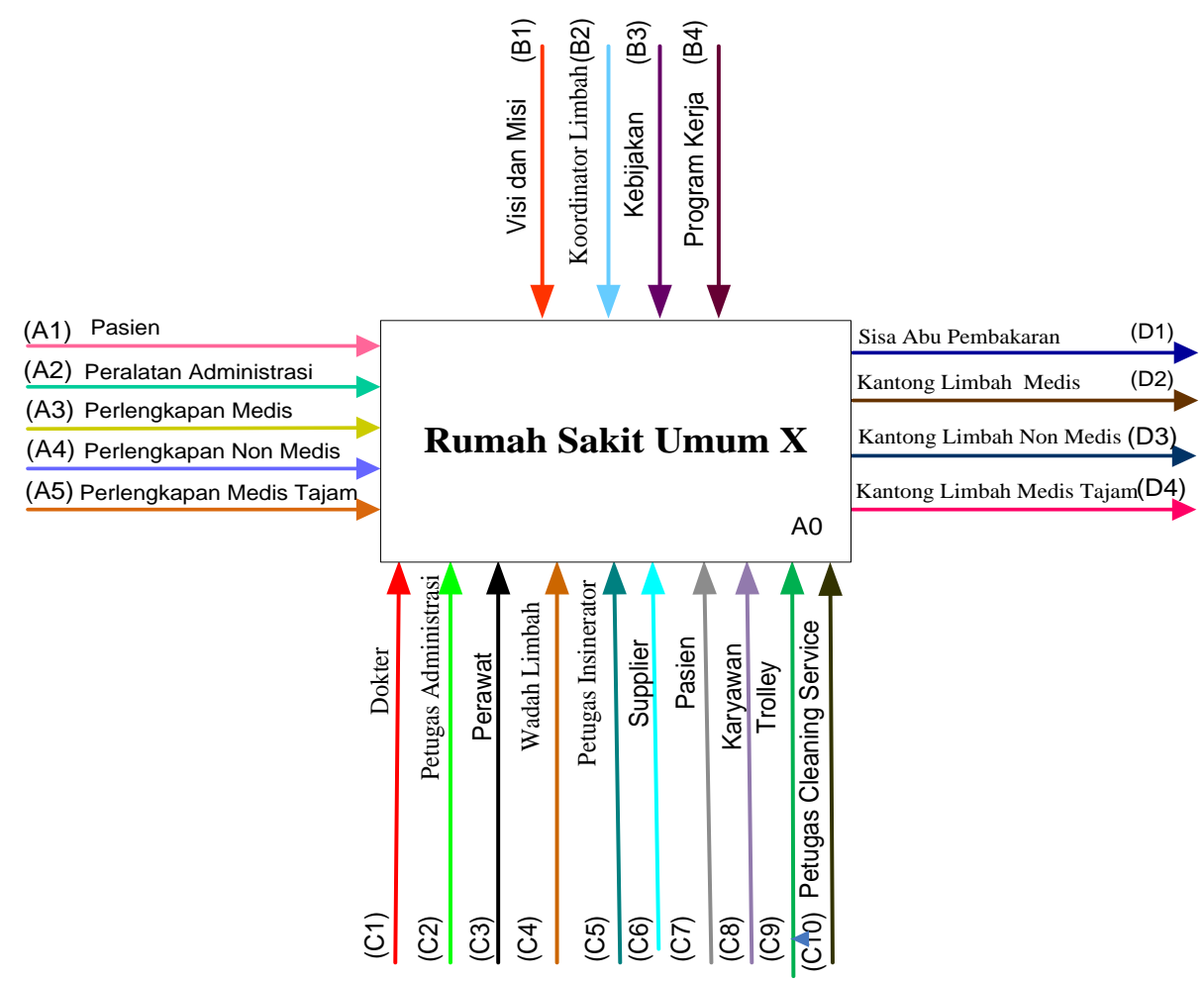

Gambar 1 Diagram Konteks Awal IDEF0 level 0 layanan utama 
Berdasarkan Gambar 1 Diatas dapat diketahui bahwa kegiatan operasional rumah sakit pada proses bisnis yang dilakukan dapat diidentifikasi menjadi 26 kelompok. Pada proses input (A) terdiri dari pasien, peralatan administrasi, perlengkapan medis, peralatan non medis dan peralatan medis tajam. Pasien (A1) merupakan input berupa pasien baru yang sedang sakit dan dirujuk ke rumah sakit dengan membutuhkan penanganan rawat inap selama pasien menginap dirumah sakit, serta kegiatan pasien yang diberikan oleh pelayanan rumah sakit. Peralatan Administrasi (A2) merupakan peralatan yang digunakan pada umumnya dalam proses administrasi seperti kertas, alat-alat tulis yang digunakan untuk memasukkan data pasien dan lainnya. Peralatan Medis (A3) merupakan peralatan yang digunakan secara langsung terhadap penanganan pasien yang diberikan secara umum membawa kontaminasi yang terdiri kapas, perban, kasa, jarum, suntik, ampul, spuit, pipet, handscoon, masker, set 1 infus, linen. Perlengkapan Non Medis (A4) merupakan hasil dari penggunaan suatu perlengkapan penunjang dari non medis seperti kertas, alat tulis. Perlengkapan Medis Tajam (A5) merupakan perlengkapan penunjang secara langsung dan terkontaminasi oleh pasien seperti pecahan gelas, pecahan termometer, jarum suntik, pipet, pisau bedah dan alat medis lainnya.

Proses control (B) ini terdiri dari visi dan misi, koordinator limbah, kebijakan dan program kerja. Visi dan Misi (B1) merupakan gambaran masa depan dengan menentukan tujuan dan cita cita yang ingin dicapai dan yang bisa dilakukan dengan langkah-langkah strategi yang belum tercapai. Koordinator Limbah (B2) merupakan koordinator limbah untuk memantau pengelolaan limbah selama dirumah sakit sampai ke tahap proses instalasi sanitasi. Kebijakan (B3) merupakan kebijakan yang dilakukan selama kegiatan operasional maupun kegiatan pengelolaan limbah dilakukan sesuai yang ditetapkan. Program Kerja (B4) merupakan program kerja rumah sakit yang mengatur bagaimana penggunaan input dalam proses mengelola limbah. Program kerja tiap limbah juga berbeda sesuai dengan jenis limbah yang dihasilkan seperti limbah medis, limbah medis tajam dan limbah non medis.

Proses mekanisme (C) ini terdiri dari dokter, petugas administrasi, perawat, wadah limbah, petugas incinerator, supplier, distribusi, karyawan, trolley. Dokter (C1) merupakan seorang tenaga kesehatan yang menjadi tempat kontak pertama pasien untuk menyelesaikan semua masalah kesehatan yang dihadapi.Petugas Administrasi (C2) merupakan seorang petugas yang menangani segala hal administrasi dari proses awal sampai akhir seperti data pendaftaran pasien baru, pelayanan dan data pelaporan hasil akhir.Perawat (C3) merupakan orang yang mengasuh dan merawat pasien yang mengalami masalah pada kesehatan selama rawat inap pasien dirumah sakit.Wadah Limbah (C4) merupakan tempat atau wadah yang digunakan untuk menampung limbah dari tiap bagian instalasi rumah sakit. Petugas Incinerator (C5) merupakan petugas yang bertugas melakukan pembakaran limbah medis dengan menggunakan mesin pembakar atau incinerator.Supplier (C6) merupakan seseorang atau perusahaan yang secara kontinu menjual barang ke perusahaan, biasanya sebagai penyedia produk kebutuhan yang relative untuk dijual. Pasien (C7) pada pasien dalam mekanisme merupakan entitas yang bekerja sama dengan staf kesehatan dalam segala proses yang berhubungan dengan aktivitas medis yang dilakukan dirumah sakit. Incinerator (C8) merupakan mesin yang digunakan untuk membakar limbah medis, limbah non medis maupun limbah medis tajam. Trolley (C9) merupakan alat yang digunakan untuk mengangkut limbah oleh petugas dari tiap instalasi oleh petugas cleaning service.Petugas Cleaning Service (C10) merupakan petugas yang bertugas untuk melakukan pengumpulan dan pengangkutan limbah dari tiap instalasi yang ada. 
Pada proses output (D) ini terdiri dari sisa abu pembakaran, kantong limbah medis, kantong limbah non medis, kantong limbah medis tajam. Sisa Abu Pembakaran merupakan abu yang terjadi akibat pembakaran limbah medis dengan menggunakan mesin incinerator. Kantong Limbah Medis merupakan kumpulan dari kantong kantong limbah dari tiap instalasi yang ada di tempat pembuangan sampah (TPS) dan disiapkan untuk diangkut menuju tempat pembuangan akhir (TPA) yang terdiri dari perban atau pembungkus yang kotor, cairan badan, anggota badan yang diamputasi, jarum-jarum dan semprit bekas, kantong urine dan produk darah, botol infus, ampul, botol bekas injeksi, kateter, plester, dan masker, air bilas ruang bedah dan otopsi, Jaringan yang diambil pada waktu biopsy, jaringan dan organ tubuh, potongan tungkai badan, plasenta dan cairan, obat-obatan atau bahan yang telah kedaluwarsa, popok. Kantong Limbah Non Medis merupakan kumpulan dari kantong kantong limbah dari tiap instalasi yang ada di tempat pembuangan sampah dan disiapakan untuk diangkut menuju tempat pembuangan akhir yang terdiri dari Kertas, Botol, sisa makanan, Karton, kertas bungkus, kaleng, botol, sampah dari ruang umum dan pasien, sisa makanan buangan, sisa pembungkus, sisa makanan/bahan makanan sayuran dan lainlain, Sisa pembungkus daun ranting, debu. Kantong Limbah Medis Tajam merupakan kumpulan dari kantong kantong limbah dari tiap instalasi yang ada di tempat pembuangan sampah dan disiapkan untuk diangkut menuju tempat pembuangan akhir yang terdiri dari pecahan gelas, pecahan termometer, jarum suntik, pipet, pisau bedah dan alat medis lainnya.

Tabel 1 Total Limbah RSU X

\begin{tabular}{clcccc}
\hline No & Jenis Limbah & $\begin{array}{c}\text { Jumlah } \\
\text { Kantong } \\
\text { Limbah/hari } \\
(\mathrm{Kg})\end{array}$ & $\begin{array}{c}\text { Jumlah } \\
\text { Limbah } \\
/ \text { hari } \\
(\mathrm{Kg})\end{array}$ & $\begin{array}{c}\text { Jumlah } \\
\text { Kantong } \\
\text { Limbah/bulan } \\
(\mathrm{Kg})\end{array}$ & $\begin{array}{c}\text { Jumlah } \\
\text { Limbah } \\
/ \text { bulan } \\
(\mathrm{Kg})\end{array}$ \\
\hline 1 & Limbah Non Medis & 335 & 60 & 1800 & 10053 \\
\hline 2 & Limbah Medis & 206 & 56 & 1680 & 6180 \\
\hline 3 & $\begin{array}{l}\text { Limbah Medis } \\
\text { Tajam }\end{array}$ & 205 & 56 & 1680 & 6150 \\
\hline & Total & $\mathbf{7 4 6}$ & $\mathbf{1 7 2}$ & $\mathbf{5 1 6 0}$ & $\mathbf{2 2 3 8 3}$ \\
\hline
\end{tabular}

Tabel 1 Total limbah RSU X diatas menjelaskan bahwa total limbah non medis, limbah medis, limbah medis tajam diperoleh dari kegiatan operasional rumah sakit yang dihasilkan selama per bulan.

Spesifikasi jumlah bahan material yang didapatkan dari bahan material limbah non medis, limbah medis dan limbah medis tajam diperoleh dari jenis raw material seperti kertas dan alat tulis, sisa makanan, sisa minuman, daun ranting, botol minuman, bekas perban, kapas, kassa, potongan tubuh, sarung tangan, ampul, masker, obat-obatan, kantong darah, linen, spuit, jarum suntik, termometer, pipet dan lainnya yang dapat ditunjukkan pada Tabel 2 dan Tabel 3. Untuk pemakaian air dan penggunaan listrik di asumsikan selama satu bulan. Dalam penggunaan air kebutuhan air sekitar $5745 \mathrm{~m}^{3} /$ bulan. Sedangkan untuk pemakaian listrik di asumsikan dalam penggunaan listrik di Indonesia electricity, oil at power $0,263548207 \mathrm{kwh}$, natural gas,burned in power 0,084569942 kwh, electicity hydropower 0,069069292 kwh.Setelah data tekumpulkan maka langkah selanjutnya yaitu dengan melakukan input yang dilakukan pada software simapro. Pada tahap penilaian dampak dilakukan penentuan 
dampak terhadap lingkungan yang telah diperoleh dari tahapan LCI (life cycle inventory). Pada tahap ini dilakukan beberapa langkah meliputi characteristization, damage assessment, normalization, weighting dan single score. Network ini merupakan informasi hubungan dari setiap proses yang memiliki pengaruh dalam menghasilkan dampak lingkungan pada limbah rumah sakit. Pada gambar network menunjukkan garis merah yang berpengaruh terhadap dampak lingkungan. Garis merah tebal pada gambar network menunjukkan proses yang memiliki pengaruh besar terhadap dampak lingkungan. Sedangkan garis tebal warna hijau menunjukkan nilai negatif yang berarti bahwa emisi tersebut memiliki keuntungan pada rumah sakit karena terproses sehingga tidak menghasilkan dampak lingkungan berdasarkan pengaruhnya terhadap kesehatan manusia dapat dilihat pada Gambar 2.

Tabel 2 Spesifikasi Jumlah Bahan Material

\begin{tabular}{|c|c|c|c|c|c|c|}
\hline No & $\begin{array}{l}\text { Jenis } \\
\text { Jimbah }\end{array}$ & $\begin{array}{c}\text { Jenis Raw } \\
\text { Material }\end{array}$ & $\begin{array}{c}\text { Jumlah } \\
\text { Material } \\
\text { untuk 1 } \\
\text { unit produk }\end{array}$ & Satuan & $\begin{array}{c}\text { Volume } \\
\text { limbah } \\
\text { per } \\
\text { bulan }\end{array}$ & Satuan \\
\hline \multirow{12}{*}{1} & \multirow{12}{*}{$\begin{array}{l}\text { Limbah } \\
\text { Non } \\
\text { Medis }\end{array}$} & $\begin{array}{c}\text { Kertas dan alat } \\
\text { tulis }\end{array}$ & 2,49 & $2.49 \mathrm{~kg}$ & 74,7 & $\mathrm{~kg}$ \\
\hline & & $\begin{array}{c}\text { Plastik } \\
\text { pembungkus }\end{array}$ & 1380 & $1380 \mathrm{~kg} / \mathrm{m}^{3}$ & 41400 & $\mathrm{~kg}$ \\
\hline & & Kardus & 0,16 & $0.16 \mathrm{~kg}$ & 4,8 & $\mathrm{~kg}$ \\
\hline & & Sisa makanan & 466 & 466 gram & 13980 & $\mathrm{~kg}$ \\
\hline & & Sisa minuman & 330 & $1000 \mathrm{ml}$ & 9900 & $\mathrm{~kg}$ \\
\hline & & Daun ranting & 5 & $5 \mathrm{~kg}$ & 150 & $\mathrm{~kg}$ \\
\hline & & Botol minuman & & $\begin{array}{c} \pm 1000 \\
\text { liter/per } \\
\text { hari/orang }\end{array}$ & \pm 30000 & $\mathrm{~kg}$ \\
\hline & & Karton & 200 & 200 gram & 6000 & $\mathrm{~kg}$ \\
\hline & & Kaleng & 1,6 & 1.6 gram & 48 & $\mathrm{~kg}$ \\
\hline & & Kadar Debu & 150 & $150 \mathrm{Ug} / \mathrm{m}^{3}$ & 50 & $\mathrm{~kg}$ \\
\hline & & Alat tulis & 100 & 100 gram & 3000 & $\mathrm{~kg}$ \\
\hline & & Putung rokok & $\begin{array}{c}16 / \text { batang } \\
\text { rokok }\end{array}$ & $\begin{array}{l}36.928 \mathrm{~cm} \\
\text { kubik }\end{array}$ & 2,216 & liter/bulan \\
\hline
\end{tabular}


Tabel 3 Spesifikasi Jumlah Bahan Material (Lanjutan)

\begin{tabular}{|c|c|c|c|c|c|c|}
\hline No & $\begin{array}{l}\text { Jenis } \\
\text { Limbah }\end{array}$ & $\begin{array}{l}\text { Jenis Raw } \\
\text { Material }\end{array}$ & $\begin{array}{l}\text { Jumlah Material } \\
\text { untuk } 1 \text { unit } \\
\text { produk }\end{array}$ & Satuan & $\begin{array}{c}\text { Volume } \\
\text { limbah } \\
\text { per } \\
\text { bulan }\end{array}$ & Satuan \\
\hline \multirow{20}{*}{2} & \multirow{20}{*}{$\begin{array}{l}\text { Limbah } \\
\text { Medis }\end{array}$} & Bekas perban & 0,5 & $0.5 \mathrm{~kg}$ & 500 & $\mathrm{~kg}$ \\
\hline & & Kapas & 500 & 500 gram & 150 & $\mathrm{~kg}$ \\
\hline & & Kassa & 100 & 100 gram & 30 & $\mathrm{~kg}$ \\
\hline & & Potongan tubuh & & \pm 200 (gram & \pm 200 & $\mathrm{~kg}$ \\
\hline & & Sarung tangan & $\begin{array}{l}13 \mathrm{~cm} \mathrm{x} 24 \mathrm{~cm} \\
\mathrm{x} 20 \mathrm{~cm} / 2 \mathrm{~kg}\end{array}$ & $\begin{array}{c}1 \text { box }=50 \mathrm{Pcs} \\
\text { berat } 2 \mathrm{~kg}\end{array}$ & 1500 & Psc \\
\hline & & Ampul & $\begin{array}{c}0.5 \mathrm{mg} / \mathrm{mL} \\
1 \mathrm{~mL} \times 6 \times 1 \text { 's }\end{array}$ & $0.5 \mathrm{mg}$ & 15 & $\mathrm{~kg}$ \\
\hline & & Masker & $1 \mathrm{box}=50 \mathrm{Pcs}$ & $\begin{array}{c}1 \text { box }=50 \text { psc } \\
\text { berat10 gr }\end{array}$ & 300 & $\mathrm{~kg}$ \\
\hline & & Obat obatan & 1 tablet & $\begin{array}{c}\text { tablet }=200 \\
\text { mg }\end{array}$ & 600 & $\mathrm{~kg}$ \\
\hline & & $\begin{array}{l}\text { Botol infus satu } \\
\text { set }\end{array}$ & 500 & $500 \mathrm{ml}$ & 560 & $\mathrm{~kg}$ \\
\hline & & Plester & $5 \mathrm{~cm} \times 4.5 \mathrm{~cm}$ & $0.2 \mathrm{~kg}$ & 6 & $\mathrm{~kg}$ \\
\hline & & Popok bekas & & $2-5 \mathrm{~kg}$ & 100 & $\mathrm{~kg}$ \\
\hline & & Kantong urin & 2000 & $2000 \mathrm{ml} /$ botol & 60000 & $\mathrm{~kg}$ \\
\hline & & Kantong darah & $16 \mathrm{G} \times 11 / 2 "$ & $240 \mathrm{ml} / \mathrm{botol}$ & 30 & $\mathrm{~kg}$ \\
\hline & & Catheter & 22 G x 1" & $1 \mathrm{box}=50 \mathrm{Pcs}$ & 15 & $\mathrm{~kg}$ \\
\hline & & $\begin{array}{l}\text { Gelang } \\
\text { Identitas } \\
\text { Pasien }\end{array}$ & $2 \mathrm{~cm} \mathrm{x} 24 \mathrm{~cm}$ & $1 \mathrm{box}=100 \mathrm{Pcs}$ & 20 & $\mathrm{~kg}$ \\
\hline & & $\begin{array}{l}\text { Bekas cairan } \\
\text { obat }\end{array}$ & 500 & $500 \mathrm{ml} /$ botol & 150 & $\mathrm{~kg}$ \\
\hline & & $\begin{array}{l}\text { Botol bekas } \\
\text { injeksi }\end{array}$ & 5 & $5 \mathrm{ml} /$ botol & 150 & $\mathrm{~kg}$ \\
\hline & & Cairan infus & 500 & $500 \mathrm{ml} /$ botol & 1500 & $\mathrm{~kg}$ \\
\hline & & Linen & 7,5 & $7.5 \mathrm{~kg} /$ orang & 47700 & $\mathrm{~kg}$ \\
\hline & & Spuit Terumo & $23 \mathrm{G} \times 1$ 1/4" ( & 1 box $=100$ Pcs & 300 & $\mathrm{~kg}$ \\
\hline \multirow{7}{*}{3} & \multirow{7}{*}{$\begin{array}{l}\text { Limbah } \\
\text { Medis } \\
\text { Tajam }\end{array}$} & Jarum suntik & $23 \mathrm{G} \times 1$ 1/4" ( & 1 box $=100 \mathrm{Pcs}$ & 3000 & $\mathrm{~kg}$ \\
\hline & & Pipet & 5 & $5 \mathrm{ml} /$ botol & 300 & $\mathrm{~kg}$ \\
\hline & & $\begin{array}{l}\text { Pecahan } \\
\text { termometer }\end{array}$ & 0,2 & $0.2 \mathrm{Pcs} / \mathrm{kg}$ & 152 & $\mathrm{~kg}$ \\
\hline & & $\begin{array}{l}\text { Pecahan gelas, } \\
\text { piring }\end{array}$ & & $\pm 2 \mathrm{~kg}$ & 120 & $\mathrm{~kg}$ \\
\hline & & $\begin{array}{l}\text { Safety box } \\
\text { medical waste }\end{array}$ & $\begin{array}{c}8 \text { liter }(27 \times 21 \\
\times 17 \mathrm{~cm})\end{array}$ & $1 \mathrm{box}=120 \mathrm{Pcs}$ & 3600 & $\mathrm{~kg}$ \\
\hline & & $\begin{array}{l}\text { Gunting } \\
\text { (Korentang set) }\end{array}$ & 1 & $1 \mathrm{~kg}$ & 12 & $\mathrm{~kg}$ \\
\hline & & Pisau bedah & 0,2 & $0.2 \mathrm{Pcs} / \mathrm{kg}$ & 3 & $\mathrm{~kg}$ \\
\hline
\end{tabular}




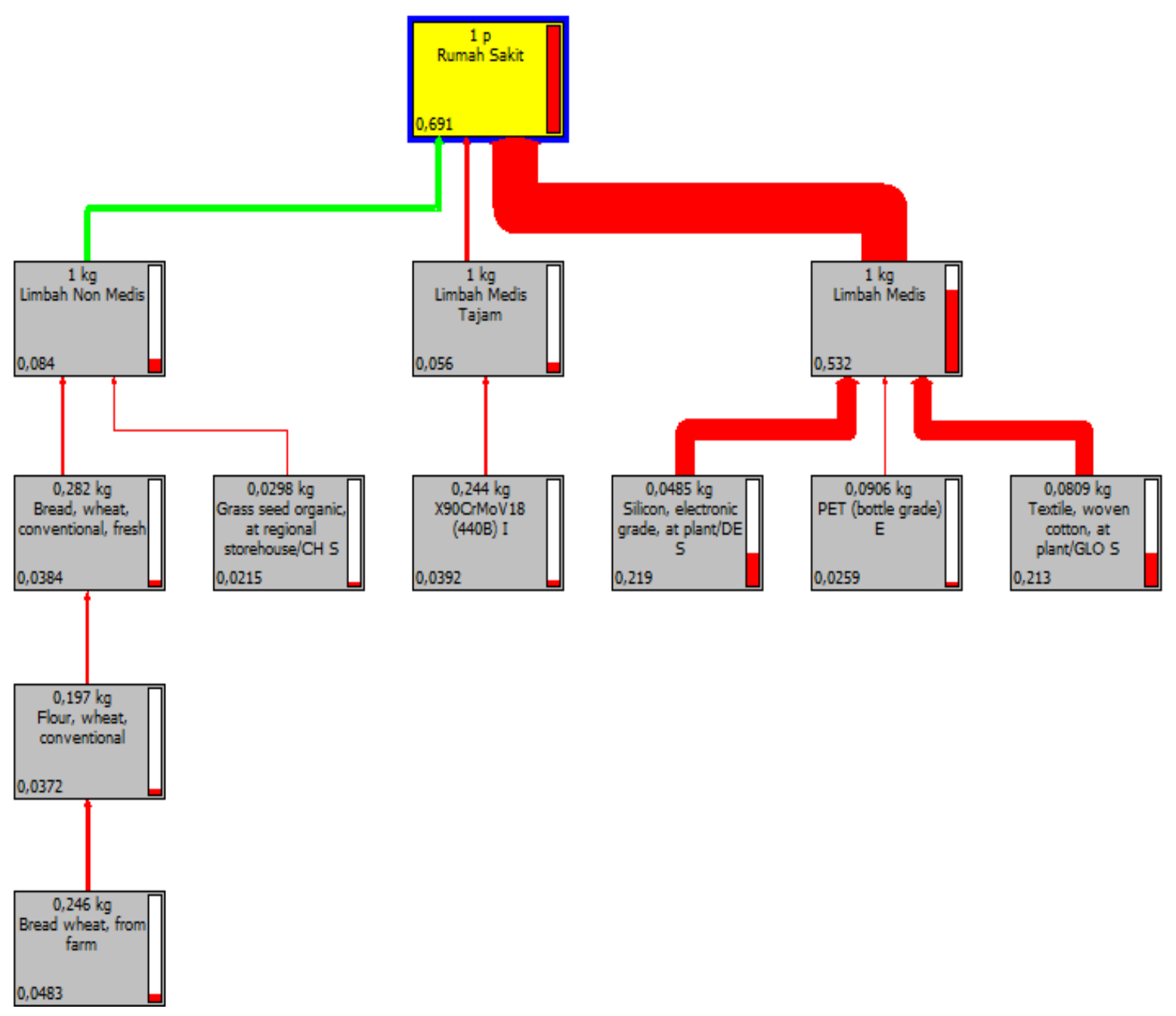

Gambar 2 Network Dampak Lingkungan Rumah Sakit

\section{Simpulan}

Dari penelitian ini didapatkan proses bisnis dari aktivitas kegiatan operasional manajemen rumah sakit IDEF0 level (A1), proses bisnis layanan utama IDEF0 Level 2 tahap verifikasi dan registrasi level (A2), menerima pasien dan memberikan tindakan medis level (A3), rekomendasi rujuk rawat inap atau rujuk ke instalasi (A4), kegiatan operasional level (A5) dan sampai pasien keluar rumah sakit level (A6) dan pada penggunaan limbah non medis sebesar $1800 \mathrm{~kg} / \mathrm{bulan}$, limbah medis sebesar 1680 $\mathrm{kg} / \mathrm{bulan}$ dan limbah medis tajam sebesar $1680 \mathrm{~kg} / \mathrm{bulan}$, penggunaan air, dan penggunaan listrik selama satu bulan. Faktor-faktor life cycle assessment yang meliputi characteristization, damage assessment, normalization, weighting dan single score. Hasil dari LCA untuk kesehatan manusia sebesar 0.000511, kualitas ekosistem sebesar 0.000357 dan sumber daya sebesar 0.0018. Dampak lingkungan yang diakibatkan oleh rumah sakit dengan menggunakkan life cycle assessment pada metode Eco Indikator 99 untuk melihat beberapa dampak lingkungan meliputi carcinogens, respiratory organics, climate change, radiation, ozone layaer, ecotoxicity, acidification / euthrophication, land use, minerals, dan fossil fuel. Sedangkan untuk menilai dampak lingkungan pada limbah dapat dilihat dari hasil life cycle assessment berdasarkan characterization, normalization weighting dan single score. Proses yang memiliki dampak lingkungan 
dirumah sakit pada human health sebesar $0.153209 \mathrm{Pt}$, eco system quality sebesar $0.178514 \mathrm{Pt}$, dan resources 0.359308. Peningkatan dampak lingkungan terbesar adalah pada nilai single score yang terdiri dari total $0.691031 \mathrm{Pt}$ meliputi penggunaan air, penggunaan listrik, penggunaan limbah medis, limbah medis non tajam dan limbah medis tajam.

\section{Referensi}

[1] A. D. Bank, "Policy Guidelines for Reducing Vehicle Emissions in Asia," ed. Manila: Asian Development Bank, 2003.

[2] M. Xiao, Y. Lin, J. Han, and G. Zhang, "A review of green roof research and development in China," Renewable and Sustainable Energy Reviews, vol. 40, pp. 633-648, 2014.

[3] W. Adisasmito, Sistem Manajemen Lingkungan Rumah Sakit. Jakarta: Raja Grafindo Persada 2007.

[4] B. Alamsyah, "Pengelolaan Limbah Di Rumah Sakit Pupuk Kaltim Bontang untuk Memenuhi Baku Mutu Lingkungan," Program Pascasarjana Universitas Diponegoro, 2007.

[5] F. Y. E. Saputra and J. Christianti, "Pemodelan Proses Bisnis Menggunakan Idef0 Dengan Studi Kasus PT. Bank Central Asia Tbk Subang," 2013.

[6] F. Farzianpour, S. Hosseini, A. Mirsepasi, H. Honary, S. S. Hosseini, and S. Hosseini, "Internal evaluation of the department of environmental health science and engineering," American Journal of Applied Sciences, vol. 10, p. 58, 2013.

[7] L. Diaz, L. Eggerth, S. Enkhtsetseg, and G. Savage, "Characteristics of healthcare wastes," Waste management, vol. 28, pp. 1219-1226, 2008.

[8] K. Siregar, A. H. Tambunan, A. K. Irwanto, S. S. Wirawan, and T. A. TIP, "Perbandingan penilaian siklus hidup (life cycle assessment) produksi biodiesel secara katalis dari Crude Palm Oil dan Crude Jatropha Curcas Oil," Jurnal Teknologi Industri Pertanian, vol. 23, 2014.

[9] P. F. M. Hermawan, M. Abduh, and R. Driejana, "Peran Life Cycle Analysis (Lca) Pada Material Konstruksi Dalam Upaya Menurunkan Dampak Emisi Karbon Dioksida Pada Efek Gas Rumah Kaca (031K)." 